\title{
China English and Dissemination of the Chinese Culture into the English World-A Case Study of the English Versions of Liaozhaizhiyi by Contemporary Translators*
}

\author{
Haijun Li \\ College of Foreign Languages, Hunan University of Arts and Science, Changde, 415000, China \\ Email: lihj0739@163.com
}

\begin{abstract}
China English refers to the English expressions with Chinese characteristics. It is acceptable for the people in the English-speaking countries as it can meet the requirement of English development and the need of cross-cultural communication between China and the English-speaking countries. It is of significance for the dissemination of the Chinese culture into the English world. Both contemporary western and Chinese translators of Liaozhaizhiyi take advantage of China English to spread the real Chinese culture into the English world.
\end{abstract}

Index Terms - China English, Liaozhaizhiyi, dissemination of the Chinese culture into the English world

\section{China ENGLish AND ChINGLish}

China English refers to the English expressions with Chinese characteristics. It is based on international Standard English and uses transliteration or literal translation to introduce Chinese unique things into the English world. The following expressions are typical examples of China English: jiaozi（饺子）, Daoism（道）, wushu（武术）, weiqi (围棋), “four modernizations”（四个现代化）、“two civilizations”, One country, Two systems (一国两制), three Represents(三个代表), eight honors, eight shames(八荣八耻).

As an English variety, China English can be accepted by the people in the English-speaking countries. In some cases, it is even more preferred by the English readers. For example, “福娃”, the mascots of 2008 Olympic games, was firstly translated as "Friendlies", a typical standard English expression. However, "Friendlies" brought about much criticism since its birth. Liao and Qu (2006) made an investigation among scholars in Australia, U.S.A., Canada and England and found that the acceptability of "Friendlies" was in doubt. Somebody thought "it is, of course, wrong to use the word Friendlies"; somebody maintained that "Friendlies"did not "convey a very clear impression of what is actually meant"; other people even stated: "I have to admit that several foreigners I know have laughed at the name "Friendlies". One year after its birth, "Friendlies"was replaced by "Fuwa", which is a typical China English and is widely accepted now by the people all over the world.

China English is different from chinglish which is unidiomatic and unacceptable English expressions caused by the negative influence of Chinese in translation. In C-E translation, if the translator makes a mechanical translation of the Chinese original expressions or follows mechanically the grammatical structure of the Chinese original, chinglish will arise inevitably. Chinglish in C-E translation mainly includes unnecessary modifier, unnecessary repetition and dangling structure. "New innovations have aroused attention from the world" is a typical example of unnecessary modifier because the meaning of the modifier "new" is included in the modified "innovations"; "We must practice economy and reduce unnecessary expenditures" is a typical example of unnecessary repetition because "practice economy" and "reduce unnecessary expenditures" have the same meaning; "Using either military or peaceful means, most of the remaining enemy forces were put out of action" is a typical example of dangling structure because the logical subject of subordinate clause is not consistent with the subject of the main clause.

\section{ACCEPTABILITY OF CHINA ENGLiSH: LinguisTiC AND CULTURAL MotivATION}

China English is acceptable for the people in the English-speaking countries as it can meet the requirement of English development and the need of cross-cultural communication between China and the English-speaking countries.

As we know, language is in constant development. There are many factors which promote the development of language, among which influence from foreign languages is an important one. Any language can not be free from

\footnotetext{
* This article is supported by National Social Science Funds (09BWW013); Scientific Funds of Education Bureau of Hunan (10B705) and Hunan Social Science Funds (2010WLH35)
} 
influence from other languages and foreign elements are necessary for it to develop. Take modern Chinese as an example. The development of modern Chinese is deeply influenced by English. Modern Chinese absorbed many elements in English during its development. Nowadays, there are many Chinese expressions which are borrowed directly from English. For examples, “掉鳄鱼眼泪” is from “to shed crocodile's tears”; “巧克力” is from “chocolate”, and so on.

English is a language most widely used in the world. It keeps developing by absorbing foreign elements from other languages. In fact, the development of the English language can not be dependent from the contribution from many other languages. The Chinese language also plays an important role for the development of the English language. English borrowed a lot of expressions from Chinese via the "bridge" of China English to express the unique things in China. Investigation shows that in the Oxford English Dictionary, there are more than 1000 English expressions originated from Chinese, covering Chinese biology, geography, art, philosophy, economics, ethics, occupations, dynasty, clothes, entertainment, association, medicine, wushu, etc. to sum up, China English can enrich English and is of significance for its development.

Cross-cultural communication includes cultural import and cultural export, which are mainly done by translation. The ideal cross-cultural communication is characterized by a balance between cultural import and cultural export. However, the cross-cultural communication between China and western countries is out of balance. We do much better in cultural import than in cultural export, which is far from the ideal cross-cultural communication. During the long course of Chinese history, the Chinese people created splendid culture, which is an important part of world cultures and should be introduced to the people of other countries so that it can make a contribution to the world cultures and people of other countries can experience and enjoy it. Therefore, when we try to import western culture into China, we should also do our best to export Chinese culture into the western world through translation, for which China English is an effective way to describe and introduce the uniqueness of the Chinese culture to the westerners.

\section{China English And Dissemination OF Chinese Culture InTO THE ENGLish World}

China English boasts its advantages in translating and introducing the Chinese culture into the English world. Firstly, it is unique in its form and thus can impress deeply the English readers; secondly, it can express the accurate meaning of the Chinese original and thus convey accurately the Chinese culture to the English readers. Today, China is experiencing rapid social and economic development. It will cast greater and greater influence upon international affairs. As a result, more and more westerners are interested in China and the Chinese culture, for which the "China fever" all around the world is a solid proof. Therefore, it is now the best time to use China English to introduce China and the Chinese culture to the western world. In the following paragraphs, the author will take some typical examples from the English version of Liaozhaizhiyi to illustrate the important role China English for dissemination of the Chinese culture to the English world.

Liaozhaizhiyi, a wenyan short story collection by $\mathrm{Pu}$ Songling with fancy and complex plots, concise style and orderly narration, is regarded as the wenyan short story masterpiece in the Chinese history of literature. It is not only well-known in China, but also loved by the people of other countries in the world through translation. Among its versions of nearly 20 different languages, the English versions of Liaozhaizhiyi boast the greatest quantity and have the greatest influence. From 1842, when Karl Friedrich August Gutzlaff introduced and translated Liaozhaizhiyi into the English world for the first time, to 2008, when Sidney L. Sondergard published the latest English version of Liaozhaizhiyi, many translators from different countries and with different professions took part in the translation of Liaozhaizhiyi into English and gave birth to nearly 20 whole-book versions and 100 single-story versions. Liaozhaizhiyi has already fulfilled its canonization in the English world.

The English translation of Liaozhaizhiyi mainly underwent two periods. During the first period (from 1840s to 1940s) when many western sinologists threw themselves into the English translation of Liaozhaizhiyi, the western culture was in a strong position while the Chinese culture a weak position. Most of the western scholars regarded the western culture as the center of the world cultures and rejected other cultures. Under the influences of "western cultural centralism" and their colonizing or missionizing translation purposes, western sinologists often manipulated the original in the English translation of Liaozhaizhiyi. The second period (from 1950s to now), when many contemporary western sinologists and Chinese scholars and translators participated in the English translation of Liaozhaizhiyi, witnessed the rapid globalization and the rising of China. During this period, the western scholars gradually freed themselves from shackles of "western cultural centralism" and began to advocate coexistence of diverse cultures and embrace other cultures. And the Chinese scholars and translators attempted to strengthen China's cultural "soft power" in the world and enrich the world cultures by translating the Chinese culture into other countries. Therefore, the western sinologists respected more and more the "foreign" culture in the original when they translated Liaozhaizhiyi into the English world. And the Chinese scholars and translators adhered to the principle of "seeking harmony without uniformity" and tried every means to present real Chinese culture before the English readers when they translated Liaozhaizhiyi into the English world so that the Chinese culture could coexist harmoniously with other cultures.

Denis C. Mair, Victor H. Mair, John Minford and Sidney L. Sondergard are representative contemporary western sinologists who translated Liaozhaizhiyi into English. Denis C. Mair and Victor H. Mair, two famous contemporary American sinologists, published in 1989 Strange Tales from Make-do Studio which comprises 51 stories from 
Liaozhaizhyi and is widely enjoyed by the English readers. John Minford, a contemporary British sinologist good at Chinese literature and well-known for his English translation of Hongloumeng(The Story of A Stone) with David Hawks, published Strange Tales from a Chinese Studio which includes 104 stories from Liaozhaizhiyi in 2006. Sidney L. Sondergard, a contemporary American sinologist shifting his academic interest from the British renaissance literature to the Chinese literature trying to translate all stories of Liaozhaizhiyi into English, published Strange Tales from Liaozhai(Vol.1,2) in 2008. The representative contemporary Chinese translators of Liaozhaizhiyi include Yang Xianyi et al., Lu Yunzhong et al. and so on. Yang Xianyi and Gladys Yang, a Chinese couple famous for their translation of a great quantity of Chinese classics into English, published Selected Tales of Liaozhai which includes 17 stories from Liaozhaizhiyi and is the first English book-version of Liaozhaizhiyi published in China. Lun Yunzhong, Chen Tifang, Yang Liyi and Yang Zhihong, four senior English scholars and experienced translators, published in 1982 Strange Tales of Liaozhai which includes 50 stories from Liaozhaizhiyi.

Both contemporary western and Chinese translators of Liaozhaizhiyi wanted to spread the real Chinese culture into the English world by translation. Therefore, they took advantage of China English, the best "bridge" for cross-cultural communication between the Chinese and western cultures, to reproduce the Chinese culture in the English versions of Liaozhaizhiyi. China English in their versions is mainly shown in their translation of the culturally-loaded expressions in Liaozhaizhiyi. Firstly, they translated the culturally-loaded words in Liaozhaizhiyi with transliteration. For example, “秀才”, “举人” and “进士” are three culturally-loaded expressions which appear most frequently in Liaozhaizhiyi. These contemporary translators translated them into "xiucai", "juren" and "jinshi" respectively, which are typical China English. They also took into consideration their readability for the English readers and added necessary notes after each version: Xiucai(The lowest degree conferred on successful candidates under the old civil service examination system); Juren(A successful candidate in the provincial examination under the former civil service examination system); Jinshi( A successful candidate in the metropolitan (held in the capital) civil service examination). As a result, the versions can present the real Chinese culture before the English readers. However, the early translators of Liaozhaizhiyi usually translated them into "bachelor's degree", "master's degree", "doctor's degree", which eliminated the foreigness of the Chinese culture. Similarly, contemporary translators translate “尺” into“chi”instead of “foot”, “衙 门”into“yamen”instead of “police”, “琴瑟”into"Qin and Se” instead of"lute and zither”, etc. Secondly, they translated the culturally-loaded expressions in Liaozhaizhiyi with literal translation. For example, John Minford translated “断袖 之癖” as “Cut Sleeve persuasion” and explained it with necessary note; Denis C. Mair and Victor H. Mair translated “衙官屈、宋” into“you are good enough to lord it over famous poets of antiquity like Qu Yuan and Song Yu”; Sidney L. Sondergard translated “相如之贫”into“as poor as Sima Xiangru”. However, the early translators translated“衙官屈、 宋”into “talented scholar”, “相如之贫”翻译成“extremely poor”, which reduced the strangeness of the Chinese culture to zero.

\section{CONCLUSION}

With time going on, China English will be accepted by more and more people in the English-speaking countries because it can meet the requirement of English development and the need of cross-cultural communication between China and English-speaking countries. It will play a more and more important role in the cross-cultural communication between the Chinese and western cultures. Therefore, we should make a full use of China English to translate and introduce the Chinese culture into the western world so that the Chinese culture can coexist harmoniously with other cultures in the world.

\section{REFERENCES}

[1] Liao, Sheng\&Qu, Zhen. (2006). A Study of the English Translation of “福娃”: Perspective of Skopostheorie. Journal of Shanghai Translators, 2, 54-57

[2] Lu, Yunzhong et al. (1982). Strange Tales of Liaozhai. Hong Kong: Commercial Press.

[3] Mair, Denis C. \& Mair,Victor H. (1989). Strange Tales from Make-do Studio. Beijing: Foreign Languages Press.

[4] Minford, John. (2006). Strange Tales from a Chinese Studio. London: Penguin Books Ltd.

[5] Sondergard, Sidney L. (2008). Strange Tales from Liaozhai. Vol. (1)(2) California: Jain Publishing Company.

[6] Yang, Hsien-yi et al. (1981). Selected Tales of Liaozhai. Beijing: Chinese Literature Press.

Haijun Li was born in Shaoyang, China in 1977. He received his PH.D. degree in English Language and Literature from Shanghai University of International Studies, China in 2011.

$\mathrm{He}$ is currently an associate professor in the College of Foreign Languages, Hunan University of Arts and Science, Changde, China. His research interests include translation and cross-cultural communication.

Dr. Zhang is a member of the Hunan Translation Association. 